\title{
Geometric Accuracy Assessment for Shoreline Derived from NDWI, MNDWI, and AWEI Transformation on Various Coastal Physical Typology in Jepara Regency using Landsat 8 OLI Imagery in 2018
}

\author{
A. Wicaksono ${ }^{\mathrm{a}}$, P. Wicaksono ${ }^{\mathrm{a}}$ \\ ${ }^{a}$ Department of Geographic Information Science, Faculty of Geography, Universitas Gadjah Mada, Yogyakarta, 55281, Indonesia
}

\section{Article Info:}

Received: 11 November 2018 in revised form: 23 Dec 2018 Accepted: 10 July 2019 Available Online: 30 August 2019

\section{Keywords:}

geometric accuracy, shoreline, Landsat $8 \mathrm{OLI}$, water index, coastal physical typology

\section{Corresponding Author:} Arief Wicaksono

Department of Geographic Information Science, Faculty of Geography, Universitas

Gadjah Mada, Yogyakarta, 55281, Indonesia

Email:

wicaksono.arief08@gmail.com

\begin{abstract}
Landsat $8 \mathrm{OLI}$ imagery and water index utilization is expected to be able to complete the shoreline data that is difficult to obtain by using terrestrial and hydrographic surveys. In fact, coastal areas in Indonesia have a variety of coastal physical typology so that each water index characteristic in obtaining shoreline data needs to be understand in order to use water index method effectively. The objectives of this study are to map the shoreline using NDWI, MNDWI, and AWEI transformations and assess the shoreline geometric accuracy on various coastal physical typology. The shoreline derived from water index is obtained from Landsat 8 OLI imagery, while the reference shoreline for accuracy assessment is obtained from visual interpretation on PlanetScope imagery. Threshold 0 and subjective threshold based on per coastal physical typology sample experiments are used to separate land-sea. The horizontal accuracy standard of the shoreline derived from water index uses the Perka BIG No 15 in 2014 on Technical Guidelines for Basic Map Accuracy. The results consisted of 1: 100,000 scale shoreline map and shoreline geometric accuracy per coastal physical typology. Based on the shoreline geometry accuracy assessment, NDWI has the highest shoreline geometry accuracy on artificial coast $(R M S E=24.13 \mathrm{~m})$. MNDWI has the highest shoreline geometry accuracy on marine deposition coast (RMSE $=15.84 \mathrm{~m})$, land deposition coast $(R M S E=29,53 \mathrm{~m})$, and volcanic coast $(R M S E=10 \mathrm{~m})$. AWElsh has the highest shoreline geometry accuracy on organic coast (RMSE= $13,47 \mathrm{~m}$ ), while AWEInsh does not superior to any coastal physical typology.
\end{abstract}

Copyright (C) 2019 GJGP-UNDIP this open access article is distributed under Creative Commons Attribution (CC-BY-NC-SA) 4.0 International license.

How to Cite (APA 6th style):

Wicaksono, A., \& Wicaksono, P. (2019). Geometric accuracy assessment for shoreline derived from NDWI, MNDWI, and AWEI transformation on various coastal physical typology in Jepara Regency using Landsat 8 OLI imagery in 2018. Geoplanning: Journal of Geomatics and Planning, 6(1), 5572. doi: 10.14710/geoplanning.6.1.55-72

\section{INTRODUCTION}

Coastal is an area with dynamic processes, both due to natural processes and accelerated by human activities (Sutanto, 2004). One example of coastal dynamics can be observed from shoreline changes, whose rate of change differs according to the coast characteristics that can be seen from the coastal physical typology. Shoreline changes occur in a short or slow time depending on the balance between sediment movement near the coast by waves and currents (Triatmojo, 2008), topography (Sinaga \& Susiati, 2007), coastal material, tides, and wind (Dulbahri, 1983). Besides influencing ecological aspects, the shoreline also plays a role in determining the administrative boundaries of the government. Geospatial information is needed to manage the vast Indonesia area. However, with a large area of Indonesia and a very long shoreline it will take a long time to obtain data and monitor shoreline if conducted by terrestrial surveys in all parts of Indonesia.

The shoreline positions used on each map may differ depending on the purpose of mapping and selecting the sea level position. The shoreline has its own uses and its properties are complementary. This study uses the shoreline proxy of the high water line because the shoreline data obtained is intended for the management of coastal areas and small islands so that it refers to Law No. 23 of 2014 concerning Regional Government. 
Landsat imagery is an example of an image with a multispectral sensor that is widely used in Indonesia. In addition to being available for free, Landsat imagery has other advantages as stated by Tucker et al., (2004) that Landsat imagery is suitable for monitoring shoreline changes because it is the only data that records global land-sea conditions at a spatial scale of tens of meters for 37 years, multispectral characteristics, and easy acquisition. With these advantages, Landsat imagery becomes a great opportunity for researchers to be able to map and monitor changes in natural and human phenomena that occur in coastal areas. In connection with the shoreline dynamics that occur, a fast and accurate shoreline extraction method is needed through remote sensing imagery so that the process of updating shoreline data can be done in a short time and is able to complete shoreline data that is difficult to obtain through terrestrial surveys and hydrographic surveys. The publication of the Head of the Geospatial Information Agency Regulation Number 15 of 2014 concerning Technical Guidelines for Basic Map Accuracy can be used as a standard of accuracy of shoreline maps obtained through remote sensing images.

Water index transformation is a band ratio method that uses two bands of multispectral imagery and takes advantage of differences in spectral responses on different types of land cover (Sun et al., 2012). Several water index transformations that have been used in related research include NDWI (McFeeters, 1996), MNDWI (Xu, 2006), and AWEI (Feyisa et al., 2014). NDWI has the advantage of detecting water bodies in the surrounding land cover in the form of non-built land (Rokni et al., 2014), but has a weakness in the detection of the water body in the surrounding land cover in the form of built land $(X u, 2006)$. MNDWI has the advantage of detecting the water body in the surrounding land cover in the form of built up land (Xu, 2006), but has a weakness in the detection of water bodies with high sediment concentrations (Sun et al., 2012) and in waters around the port (Yang et al., 2015). Meanwhile, AWEl has advantages in water body detection in muddy coastal morphology (Li \& Gong, 2016) and is able to suppress shadow and other non-water dark surface disturbances (Feyisa et al., 2014), but has a weakness in the detection of water bodies in around the port (Yang et al., 2015) and not as good as NDWI and MNDWI in the detection of water bodies in the surrounding land cover in the form of non-built land (Rokni et al., 2014). From the results of these studies it is known that each water index transformation has advantages and limitations in the detection of water bodies, including the shoreline, in certain coastal physical typology classes. Yang et al., (2015) explains this to happen because each water index transformation is made for a specific purpose and the advantages provided by the water index transformation at that particular location will be lost when applied in another location.

From several previous studies, it can be observed that many studies link the accuracy of information from remote sensing data with land cover, but not many have examined the relationship with the coastal physical typology. In fact, the coastal physical typology is one of the mapping and analysis units in the management of coastal areas. In addition, the shoreline is one of the basic data in the mapping that must be guaranteed based on Law No. 4 of 2011 concerning Geospatial Information. The purpose of this study was to calculate the Jepara Regency shoreline geometry accuracy from NDWI, MNDWI, and AWEI transformations using 2018 Landsat 8 OLI imagery in different coastal physical typologies.

\section{DATA AND METHODS}

\subsection{Materials}

The data used in the study are Landsat 8 OLI imagery path 120 / row 64 recording March 182018 at 09:47:16, to obtain shoreline data. Obtained by accessing the website www.earthexplorer.usgs.gov. and the PlanetScope Image in Jepara Regency recording March 182018 at 09:20:29 and 09:21:45, and March 19 2018 at 10:30:45, as reference data for assessing the geometry accuracy of shorelines.

\subsection{Study Area}

Jepara Regency is located between $5^{\circ} 43^{\prime} 20.93^{\prime \prime S}$ and $6^{\circ} 47^{\prime} 25.81^{\prime \prime S}$, and between $110^{\circ} 9^{\prime} 48.81^{\prime \prime} \mathrm{E}$ and $110^{\circ} 9^{\prime} 48.04^{\prime \prime} \mathrm{E}$ is one of the districts in the northern part of Central Java Province which bordering the Java Sea, with a shoreline of $82.73 \mathrm{~km}$, including the existence of Karimunjawa (Pemerintah Kabupaten Jepara, 2012). Administrative map of Jepara Regency is shown in Figure 1. Some of the causes of shoreline dynamics that occur in Jepara Regency are oceanographic conditions (currents, winds, waves and tides), 
physical development (reclamation and embankments), cultivation (mangroves and ponds), and sedimentation in river estuaries. The problem of damage to mangrove ecosystems on the west coast of Jepara Regency and sand mining that occurred on the north coast of Jepara Regency is also the cause of shoreline dynamics due to changes in coastal morphology conditions that affect the direction and speed of ocean currents. Jepara Regency was chosen as a research area by considering the length of the shoreline that is owned, as well as the variation in the class of coastal material and land cover on the coast.

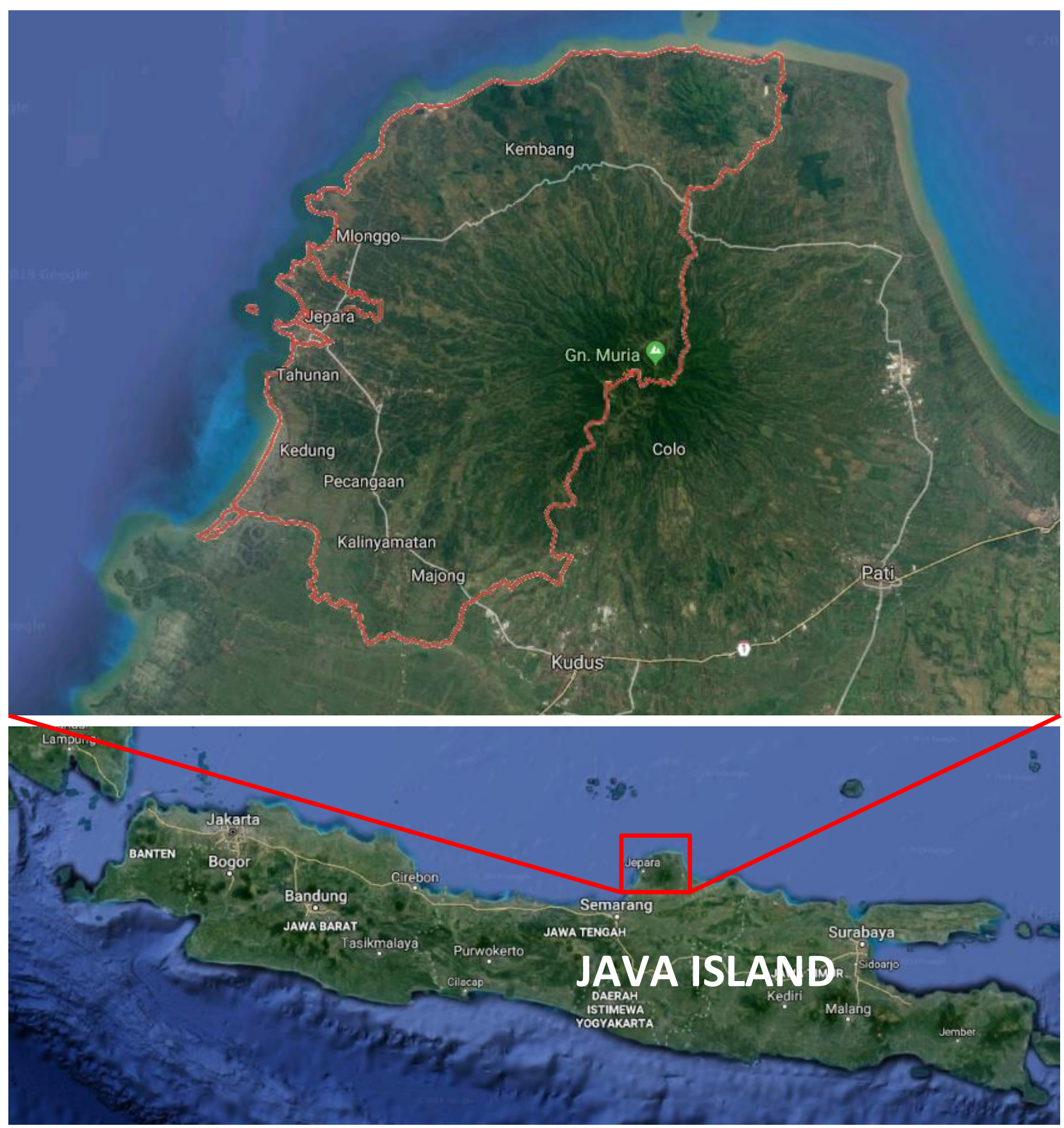

Figure 1. Administrative map of Jepara Regency

\subsection{Coastal Physical Typology}

Coastal physical typology is determined based on the process of occurrence (genesis), reliefs, and constituent materials. These three parameters relate to the landform so that it is necessary to know the type of landform in the study area. The data of each parameter is obtained from a geological map of scale 1: 100,000 sheets and slope maps derived from SRTM imagery. Relief classification used is according to van Zuidam and van Zuidam-Cancelado (1978) in (Khakim, 2009). The mapping unit in the coastal physical 
typology map is an area with symbolization distinguished by color. To facilitate the creation of a coastal physical typology map, a matrix for determining the coastal physical typology is used in Table 1.

Table 1. Matrix of determining coastal physical typology (Khakim, 2009; Rahardjo, 2003)

\begin{tabular}{|c|c|c|c|c|c|c|c|c|}
\hline \multicolumn{2}{|c|}{ Coast type } & $\begin{array}{l}\text { Land } \\
\text { erosion } \\
\text { coast }\end{array}$ & $\begin{array}{c}\text { Land } \\
\text { deposition } \\
\text { coast }\end{array}$ & $\begin{array}{c}\text { Volcanic } \\
\text { coast }\end{array}$ & $\begin{array}{c}\text { Structural } \\
\text { coast }\end{array}$ & $\begin{array}{c}\text { Marine } \\
\text { deposition } \\
\text { coast }\end{array}$ & $\begin{array}{c}\text { Wave } \\
\text { erosion } \\
\text { coast }\end{array}$ & $\begin{array}{c}\text { Organic } \\
\text { coast }\end{array}$ \\
\hline \multicolumn{9}{|c|}{$\begin{array}{l}\text { Physical typology } \\
\text { parameter }\end{array}$} \\
\hline \multirow{4}{*}{ 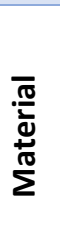 } & Mud & & V & & & V & & V \\
\hline & Sand & & v & v & & v & & \\
\hline & Rock & v & & V & V & & V & \\
\hline & Coral & & & & & & & V \\
\hline \multirow{5}{*}{ 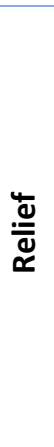 } & Flat & & v & & & V & & v \\
\hline & $\begin{array}{l}\text { Slightly } \\
\text { slope }\end{array}$ & & & & & v & & \\
\hline & $\begin{array}{l}\text { Rather } \\
\text { steep }\end{array}$ & v & & v & v & 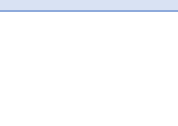 & v & \\
\hline & Steep & v & & $\sqrt{ }$ & $\checkmark$ & & $\checkmark$ & \\
\hline & Very steep & v & & V & V & & v & \\
\hline \multirow{8}{*}{ 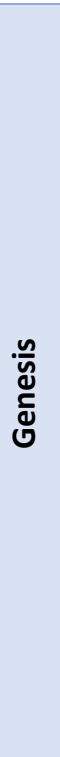 } & $\begin{array}{l}\text { Land } \\
\text { erosion }\end{array}$ & v & & & & & & \\
\hline & $\begin{array}{l}\text { Wave } \\
\text { erosion }\end{array}$ & & & & & & v & \\
\hline & $\begin{array}{l}\text { Land } \\
\text { deposition }\end{array}$ & & v & & & & & \\
\hline & $\begin{array}{l}\text { Marine } \\
\text { deposition }\end{array}$ & & & & & V & & \\
\hline & Volcanic & & & v & & & & \\
\hline & Structural & & & & v & & & \\
\hline & Solutional & V & & & & & & \\
\hline & Organism & & & & & & & v \\
\hline
\end{tabular}

\subsection{Water Indices}

These three water index transformations were chosen on the grounds of the high number of references to Google Scholar, with the number of references for NDWI (McFeeters, 1996), MNDWI (Xu, 2006), and AWEI (Feyisa et al., 2014) are 1,850 times, 1,011 times, and 224 times respectively, as well as the compatibility between the ability of these three water index transformations and geographical conditions in the study area. Water index transformation is a form of spectral sharpening that can highlight the water information so that it can be distinguished from other objects. Several formulas for water index transformation were used in this study to determine the characteristics of each water index transformation in each coastal typology. The formula used in this study is summarized in Table 2. 
Table 2. Water indices formula

\begin{tabular}{|c|c|c|}
\hline Water indices & Formula & Pixel value of water \\
\hline $\begin{array}{l}\text { Normalized Difference } \\
\text { Water Index (NDWI) oleh } \\
\text { McFeeters (1996) }\end{array}$ & NDWI = (GREEN-NIR)/(GREEN+NIR) & Positive \\
\hline $\begin{array}{l}\text { Modified Normalized } \\
\text { Difference Water Index } \\
\text { (MNDWI) oleh Xu (2006) }\end{array}$ & MNDWI = (GREEN-SWIR1)/(GREEN+SWIR1) & Positive \\
\hline $\begin{array}{l}\text { Automated Water } \\
\text { Extraction Index (AWEI) } \\
\text { oleh Feyisa et al. (2014) }\end{array}$ & $\begin{array}{c}\mathrm{AWEI}_{\text {nsh }}=4 \times(\mathrm{GREEN}-\mathrm{SWIR} 1)-(0,25 \times \mathrm{NIR}+2,75 \times \mathrm{SWIR} 2) \\
\mathrm{AWEI}_{\text {sh }}=\mathrm{BLUE}+2,5 \times \mathrm{GREEN}-1,5 \times(\mathrm{NIR}+\mathrm{SWIR} 1)-0,25 \times \\
\text { SWIR2 }\end{array}$ & Positive \\
\hline
\end{tabular}

\subsection{Threshold Selection}

Land-sea separation is done through the threshold setting on the results of the water index transformation. This land-sea separation helps facilitate shoreline detection. There are two thresholds that will be carried out in this study, namely threshold $=0$ and subjective threshold settings to obtain land-sea boundaries that are closest to the reference shoreline digitized from the PlanetScope image. In subjective threshold selection, several experiments were carried out for each water index transformation in the coastal typology sample in Jepara Regency so that the most suitable threshold of each water index transformation in each coastal physical typology sample can be known by looking at the geometry accuracy of the shoreline each trial.

\subsection{Geometric Accuracy Standard}

After the horizontal RMSE value is known, then horizontal geometry accuracy is calculated (CE90 value) obtained by the formula referring to the following US NMAS (United States National Map Accuracy Standards) standard (Badan Informasi Geospasial, 2014) and then it is classified according to Table 3.

$$
\text { CE90 }=1,5175 \times \text { RMSEr }
$$

Information:

CE90 = Circular Error $90 \%$ is a measure of horizontal geometry accuracy (in $\mathrm{m}$ ) defined as a radius of a circle indicating that $90 \%$ of errors or differences in the horizontal position of objects on a map with positions that are considered to be actually not greater than the radius.

RMSEr = Root Mean Square Error in $\mathrm{x}$ and $\mathrm{y}$ position (horizontal).

Table 3. Geometry accuracy of Indonesia Topographic Maps (RBI)

\begin{tabular}{cccc}
\multirow{2}{*}{$\begin{array}{c}\text { Scale } \\
\end{array}$} & \multicolumn{2}{c}{ Geometry accuracy of Indonesia Topographic Maps (in meters) } \\
& Class 1 & Class 2 & Class 3 \\
\hline
\end{tabular}




\section{RESULTS AND DISCUSSION}

The samples that were mask for the needs of threshold evaluation were scattered on several shorelines with variations in coastal physical typologies following Figure 2. By describing the condition of the sample location in Table 4, such as land cover, geomorphology, slope, and shoreline geometry, it can be explained about the source of errors in shoreline extraction and the causes of different threshold selection in each sample location. The land cover affects the spectral reflection value of the object in the image so that the explanation of the pixel value resulting from the water index transformation in each land cover class can be explained by making the object's spectral reflection curve.

The impact of the limited spatial resolution of Landsat $8 \mathrm{OLI}$ images is also seen in variations in the shape of the shoreline. The shape of the shoreline with high and firm variations will be difficult to identify by the image compared to the shape of a straight shore and with variations that change gradually. Information about the size of the tide range and the slope of the beach is useful in tidal correction. Geomorphological conditions explain the process that works in the sample location. This becomes more important when multi-temporal research is conducted. Several sources of errors that were successfully identified in each sample location include ponds, sediments, clouds, cloud shadows, and ports. From some of the information and the results of the RMSE calculation in the evaluation threshold experiment as shown in Figure 3, it is known that the volcanic typology sample location is the most ideal location in conducting threshold evaluation experiments and shoreline accuracy test results from water index transformation, while the land deposition and organic typology sample location are locations that is not too ideal for experiments.

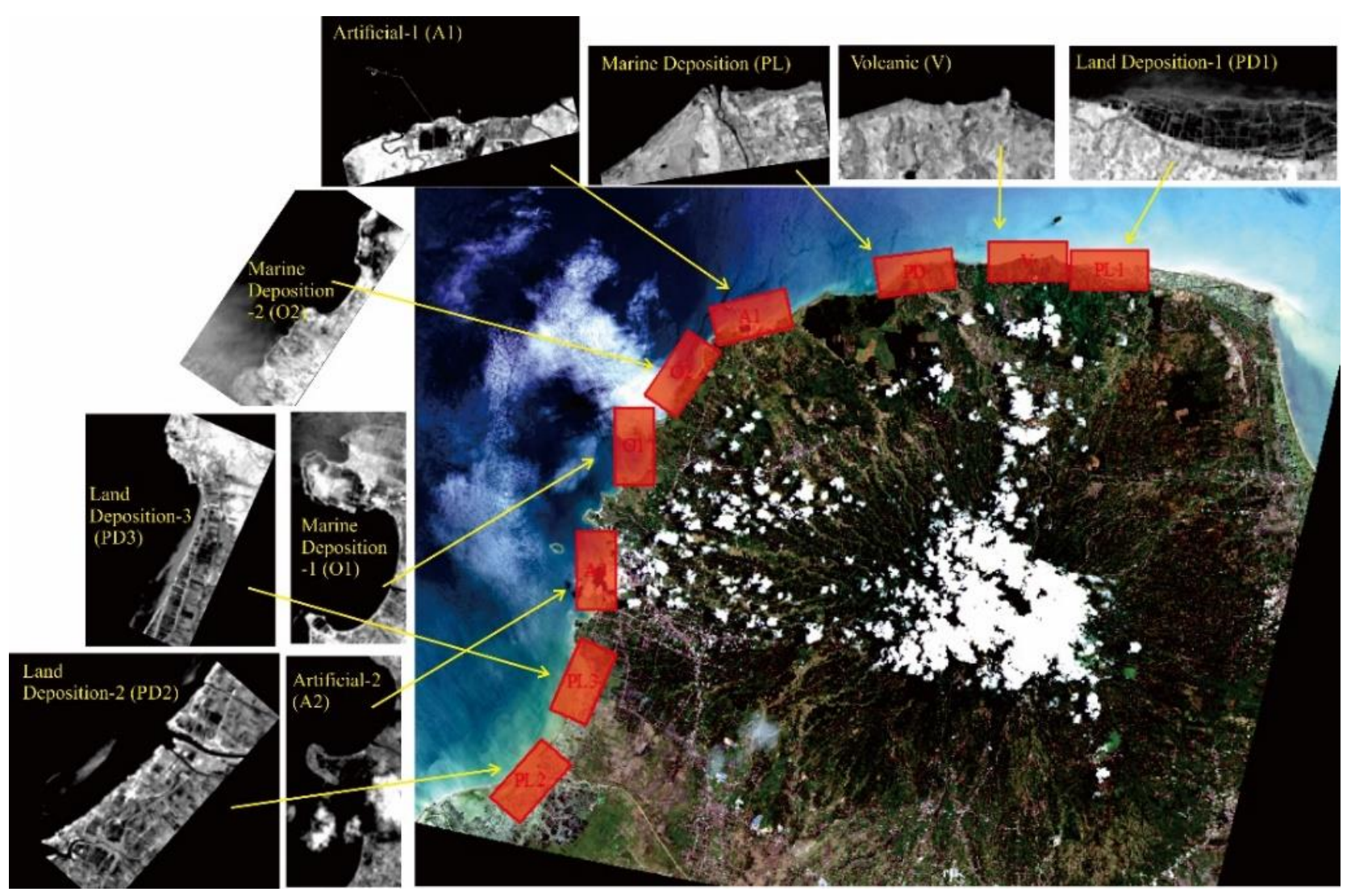

Figure 2. Sample location index of coastal physical typology for threshold evaluation 
Table 4. Location characteristics of coastal physical typology for threshold evaluation needs

\begin{tabular}{|c|c|c|c|c|c|}
\hline Typology Samples & $\begin{array}{c}\text { Dominant Land } \\
\text { Cover }\end{array}$ & Geomorphology & Slope & $\begin{array}{l}\text { Shoreline } \\
\text { Geometry }\end{array}$ & Error Source \\
\hline $\begin{array}{c}\text { Land deposition } \\
\text { coast } 2\end{array}$ & Pond & Delta & $\begin{array}{l}0-2 \% \text { (flat) to } 2.1-14 \% \\
\text { (sloping) }\end{array}$ & Irregular & Sediment, Pond \\
\hline $\begin{array}{l}\text { Land deposition } \\
\text { coast } 3\end{array}$ & $\begin{array}{c}\text { Pond and Residential } \\
\text { Buildings }\end{array}$ & Mud flat & $\begin{array}{l}0-2 \% \text { (flat) to } 2.1-14 \% \\
\text { (sloping) }\end{array}$ & $\begin{array}{l}\text { Straight and } \\
\text { curved }\end{array}$ & Sediment, Pond \\
\hline Artificial coast 2 & $\begin{array}{l}\text { Residential Buildings } \\
\text { and Harbor }\end{array}$ & $\begin{array}{l}\text { Beach, coastal } \\
\text { alluvial plain }\end{array}$ & $\begin{array}{l}0-2 \% \text { (flat) to } 2.1-14 \% \\
\text { (sloping) }\end{array}$ & Gulf and Cape & $\begin{array}{c}\text { Cloud, Cloud } \\
\text { Shadow, Harbor }\end{array}$ \\
\hline $\begin{array}{c}\text { Marine } \\
\text { deposition coast } \\
\text { (coral rubble } \\
\text { sand) } 1\end{array}$ & $\begin{array}{l}\text { Non-Volcanic Beach } \\
\text { and Pond }\end{array}$ & $\begin{array}{l}\text { Beach, coastal } \\
\text { alluvial plain }\end{array}$ & $\begin{array}{l}0-2 \% \text { (flat) to } 2.1-14 \% \\
\text { (sloping) }\end{array}$ & Gulf and Cape & Cloud \\
\hline $\begin{array}{c}\text { Marine } \\
\text { deposition coast } \\
\text { (coral rubble } \\
\text { sand) } 2\end{array}$ & $\begin{array}{l}\text { Non-Volcanic Beach } \\
\text { and Pond }\end{array}$ & $\begin{array}{l}\text { Beach, coastal } \\
\text { alluvial plain }\end{array}$ & $\begin{array}{l}0-2 \% \text { (flat) to } 2.1-14 \% \\
\text { (sloping) }\end{array}$ & Gulf and Irregular & Cloud \\
\hline Artificial coast 1 & $\begin{array}{l}\text { Harbor, Non- } \\
\text { Volcanic Beach, } \\
\text { Volcanic Beach }\end{array}$ & $\begin{array}{l}\text { Beach, coastal } \\
\text { alluvial plain }\end{array}$ & $\begin{array}{c}0-2 \% \text { (flat) to } 14.1-24 \% \\
\text { (rather steep) }\end{array}$ & Curved & Harbor \\
\hline $\begin{array}{c}\text { Marine } \\
\text { deposition coast }\end{array}$ & $\begin{array}{l}\text { Volcanic Beach and } \\
\text { Other Natural Open } \\
\text { Land }\end{array}$ & $\begin{array}{l}\text { Beach, coastal } \\
\text { alluvial plain, Spit }\end{array}$ & $\begin{array}{l}0-2 \% \text { (flat) to } 2.1-14 \% \\
\text { (sloping) }\end{array}$ & Curved & $\begin{array}{l}\text { Sediment in the } \\
\text { River Estuary }\end{array}$ \\
\hline Volcanic coast & $\begin{array}{c}\text { Volcanic Beach and } \\
\text { Highland Forest }\end{array}$ & $\begin{array}{l}\text { Shore, coastal } \\
\text { alluvial plain, } \\
\text { parasitic cone }\end{array}$ & $\begin{array}{c}0-2 \% \text { (flat) to }>40 \% \text { (very } \\
\text { steep) }\end{array}$ & Gulf and Cape & - \\
\hline $\begin{array}{l}\text { Land deposition } \\
\text { coast } 1\end{array}$ & $\begin{array}{c}\text { Pond and Volcanic } \\
\text { Beach }\end{array}$ & Mud flat & $\begin{array}{l}0-2 \% \text { (flat) to } 2.1-14 \% \\
\text { (sloping) }\end{array}$ & Irregular & Sediment, Pond \\
\hline
\end{tabular}

Landsat 8 imagery $\mathrm{OLI}$ that has been transformed by water index has pixel values with statistics as in Table 5. Each of the water index transformation results as shown in Figure 4 has different statistics. However, NDWI and MNDWI have relatively the same range of values, but with different average values and standard deviations.

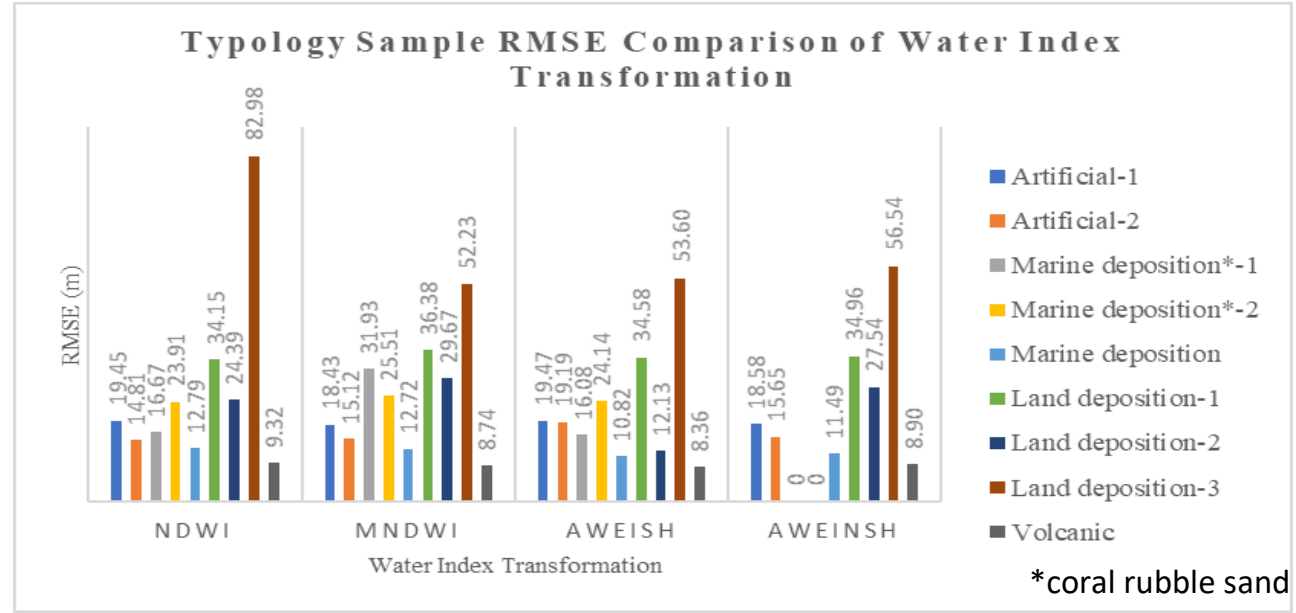

Figure 3. RMSE comparison graph in the coastal typology sample location per water index transformation with an optimal threshold based on evaluation results

Table 5. Descriptive statistics on water index transformation

\begin{tabular}{ccccc} 
Statistic & NDWI & MNDWI & AWElsh & AWEInsh \\
Min & -1 & -1 & $-1,6$ & $-5,66$ \\
Max & 1 & 1 & 1,39 & 1,91 \\
\hline Mean & $-0,3$ & $-0,17$ & $-0,23$ & $-0,37$ \\
\hline StDev & 0,54 & 0,51 & 0,34 & 0,45 \\
\hline
\end{tabular}




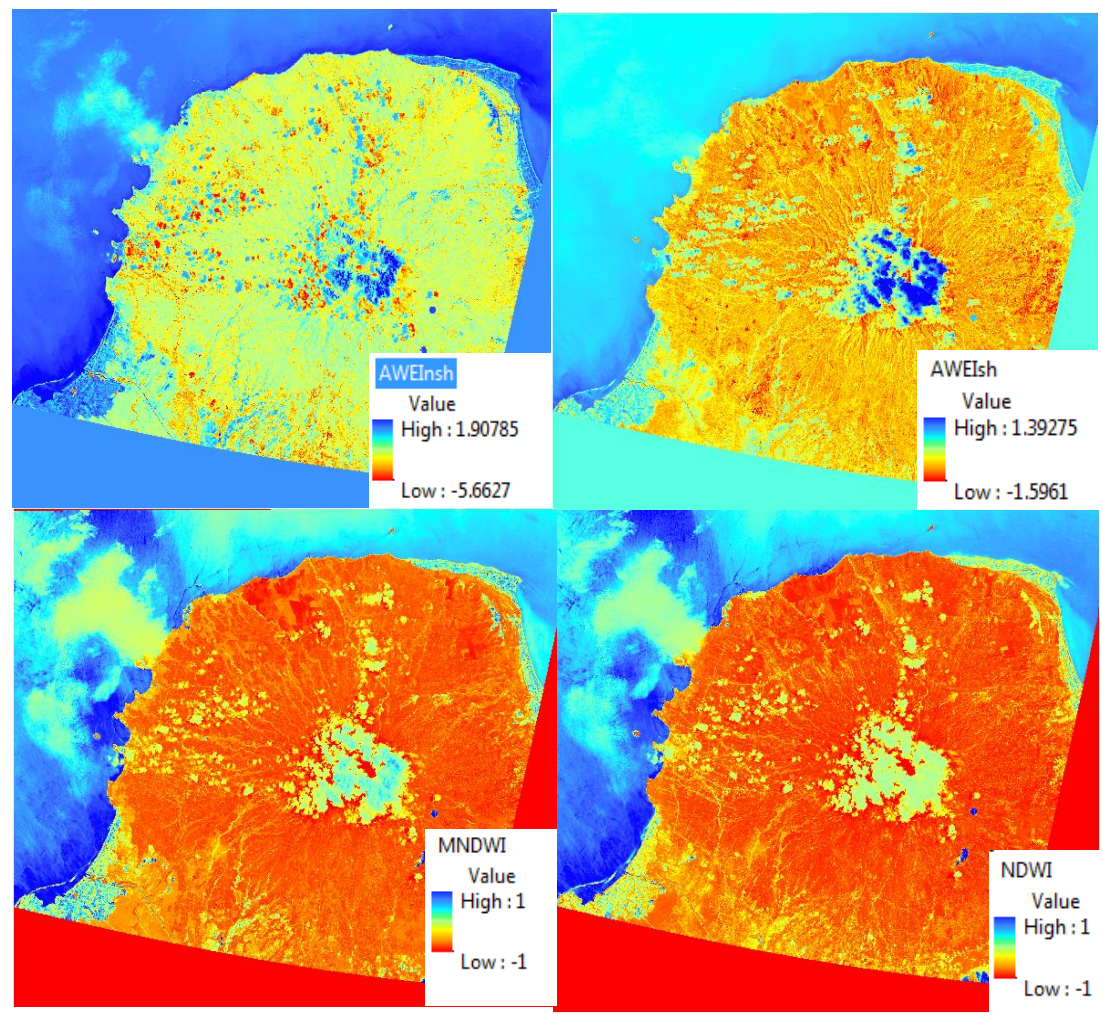

Figure 4. Image display of the water index transformation

When viewed from the image histogram in Figure 5 and Figure 6, generally the histogram between AWElsh and AWEInsh, and between NDWI and MNDWI have similar patterns. The histogram of each water index transformed image has a bimodal form, but not normally distributed. In theory, each water index transformation will show positive pixel values for water objects (McFeeters, 1996). When viewed from the histogram, the pixel value $\geq 0$ has several peaks and valleys that do not indicate a single object. On the contrary, the histogram of the $<0$ pixel value has only one peak and one valley which shows that all water index transforms are able to classify non-water objects as a class.
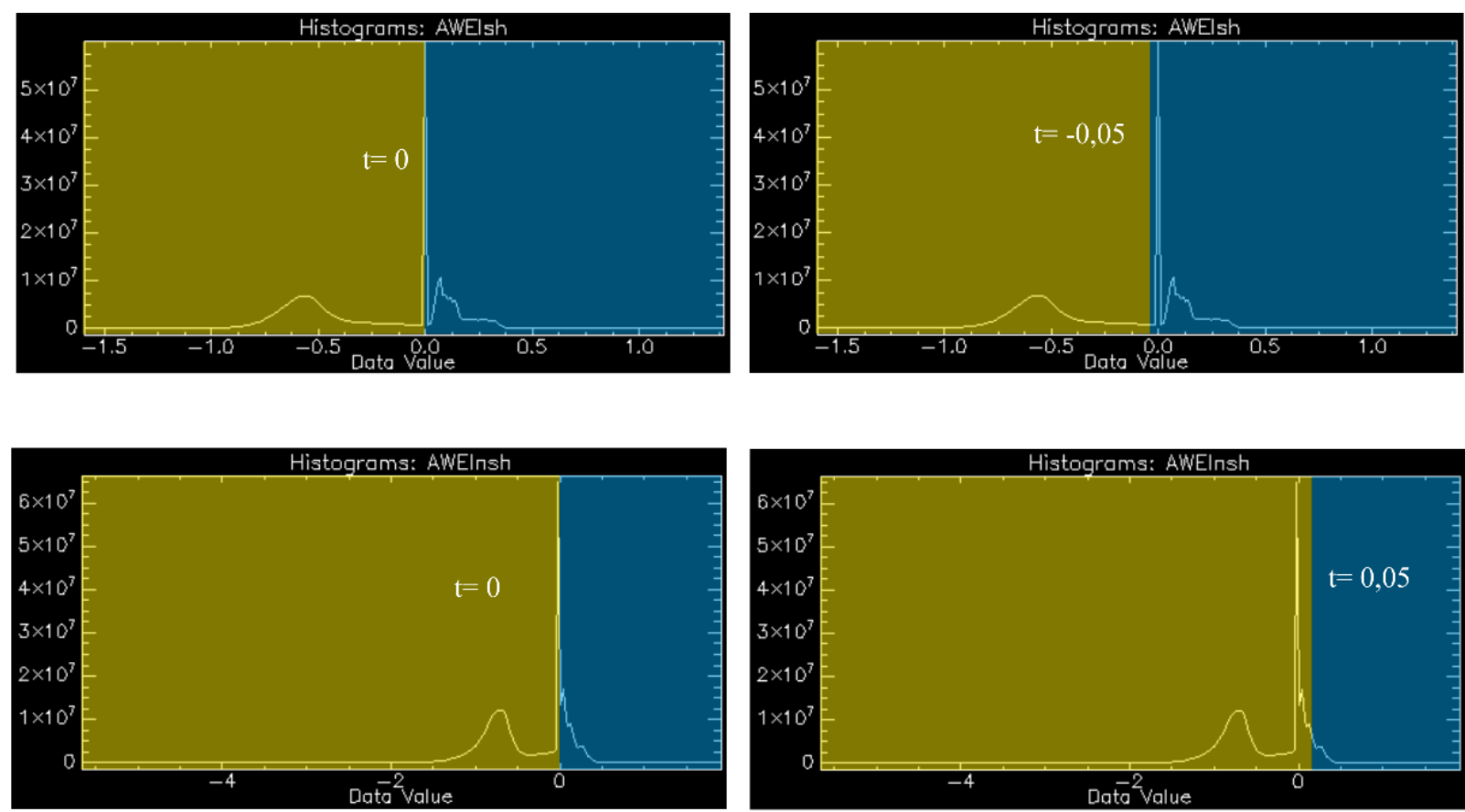

Keterangan: Non-Air Air

Figure 5. Histogram and threshold of AWEIsh and AWEInsh transformation 

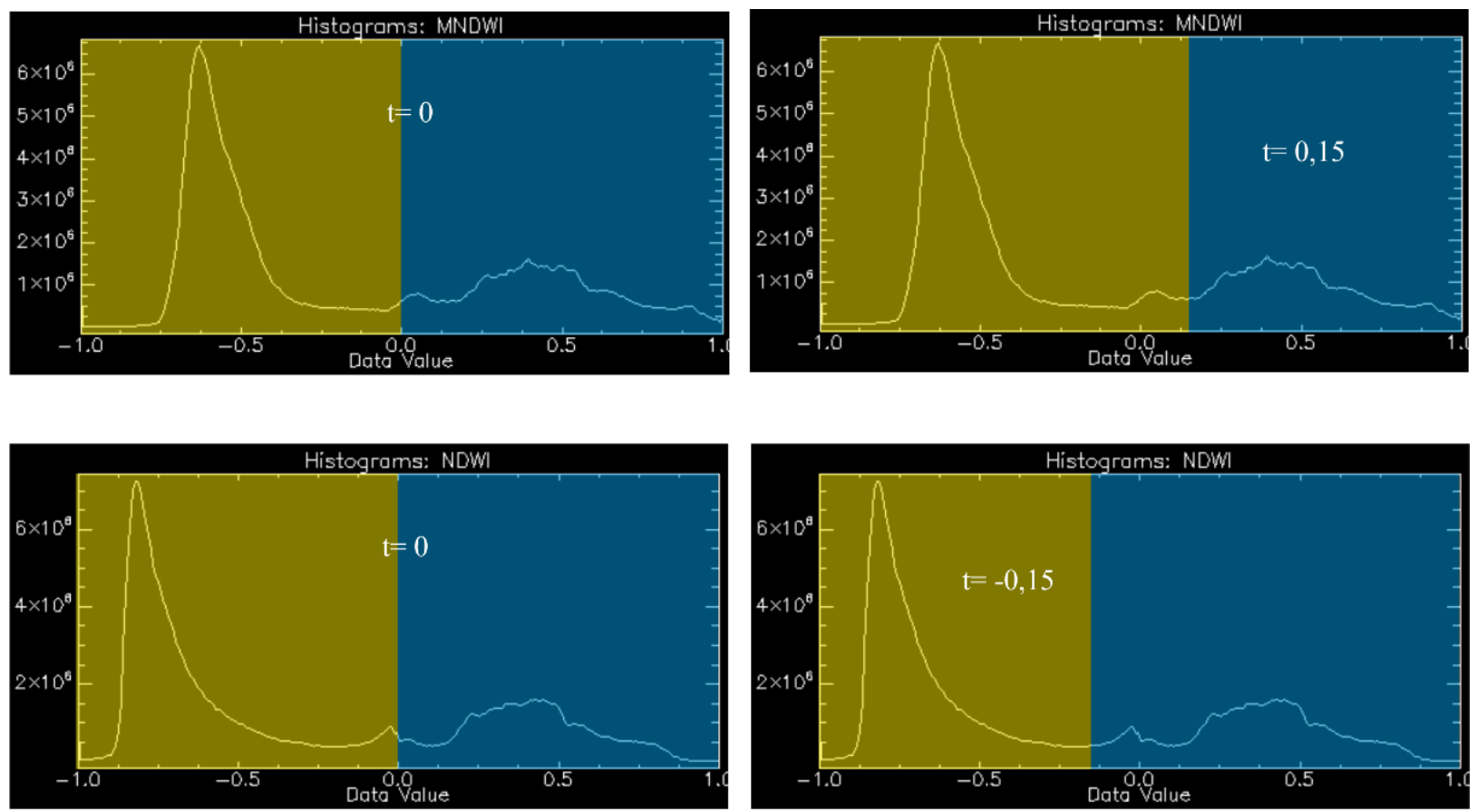

Keterangan: Non-Air

Figure 6. Histogram and threshold of MNDWI and NDWI transformation

Thus, through the appearance of the image histogram it is known that there is no single water index transformation that is directly capable of separating objects in the study area into two classes (Xu, 2006). The limitations of all water index transformations are caused by the following: (1) image conditions that are not so ideal due to cloud cover in the study area, (2) sediments around the shoreline, (3) water objects in the study area with varying shapes and sizes, (4) non-water objects that have spectral characteristics resembling water objects, and (5) non-detailed image spatial resolution resulting in many mixed pixels that have an impact on the image histogram, especially the water object histogram.

The subjective threshold is determined by conducting several experiments on each sample of the coastal physical typology as in Figure 7 . The number of experiments carried out was 265 , consisting of 7 threshold experiments in each water index transformation in each coastal physical typology sample, with a threshold range of -0.15 to 0.15 , plus a number of threshold experiments with a range of values other than -0.15 to 0.15 , if the best results are not obtained. Out of a total of 265 trials, only 67 trials were tested for accuracy. This is due to 198 other experiments with visual observations that are considered not capable of producing shoreline resembling a reference shoreline so that no accuracy test is performed.

Table 6. Determination of optimal threshold for each water index transformation in each coastal physical typology

\begin{tabular}{|ccccccccc}
\hline & \multicolumn{7}{c}{ Threshold and geometric accuracy of water indices } \\
Coastal physical typology & NDWI & $\begin{array}{c}\text { RMSE } \\
(\mathbf{m})\end{array}$ & MNDWI & $\begin{array}{c}\text { RMSE } \\
(\mathbf{m})\end{array}$ & AWEIsh & $\begin{array}{c}\text { RMSE } \\
(\mathbf{m})\end{array}$ & AWEInsh & $\begin{array}{c}\text { RMSE } \\
(\mathbf{m})\end{array}$ \\
\hline A & $-0,05$ & 14,81 & 0 & 15,12 & 0 & 19,19 & 0 & 15,65 \\
\hline O & $-0,1$ & 16,67 & $-0,05$ & 25,51 & 0 & 16,08 & - & - \\
\hline LD & $-0,15$ & 24,39 & 0,15 & 29,67 & $-0,05$ & 12,13 & 0,05 & 27,54 \\
\hline MD & 0,2 & 12,79 & 0,3 & 12,72 & 0,1 & 10,82 & 0,05 & 11,49 \\
\hline V & 0,2 & 9,32 & 0,3 & 8,74 & 0,15 & 8,36 & 0,05 & 8,90 \\
\hline Optimal threshold & $-0,15$ & 24,39 & 0,15 & 29,67 & $-0,05$ & 12,13 & 0,05 & 27,54 \\
\hline
\end{tabular}

Info: $\mathrm{A}=$ artificial, $\mathrm{O}=$ organic, $\mathrm{MD}=$ marine deposition, $\mathrm{LD}=$ land deposition, $\mathrm{V}=$ volcanic 
By conducting a threshold experiment in the coastal physical typology sample, it can be seen the optimal threshold of each water index transformation in a particular coastal physical typology class. Subjective threshold is chosen by looking at the lowest RMSE value of each water index transformation in the coastal physical typology sample, after that the subjective threshold of each coastal typology physical sample compared to each other to determine one of the most optimal thresholds in each coastal physical typology then the threshold is applied in all research areas. Optimal threshold for each water index transformation in each coastal physical typology that will be applied in all research areas is presented in Table 6. For smoothing the shoreline, this study tends to prefer the PAEK algorithm with a tolerance value of 200 for the shoreline generalization process because if observed visually the generalization of the resulting shoreline is smoother and the pattern formed is similar to the reference shoreline.

Map of the coastal physical typology of the west part of Jepara Regency can be seen in Figure 7. On a scale of 1: 100,000, the coast in Kedung Sub district is dominated by land deposition coast and pond land cover. Coastal area in Kecamatan Tahunan consists of marine deposition coast, but in locations that have coral reefs it will have organic coast, such as on Teluk Awur Beach. The land cover in the Tahunan District consists of rice fields and residential buildings. Coastal area in Jepara sub district consists of artificial and marine deposition coasts, while in some locations that have coral reefs will have organic coast, such as in Bandengan Beach, while dominant land cover classes are residential and rice fields.

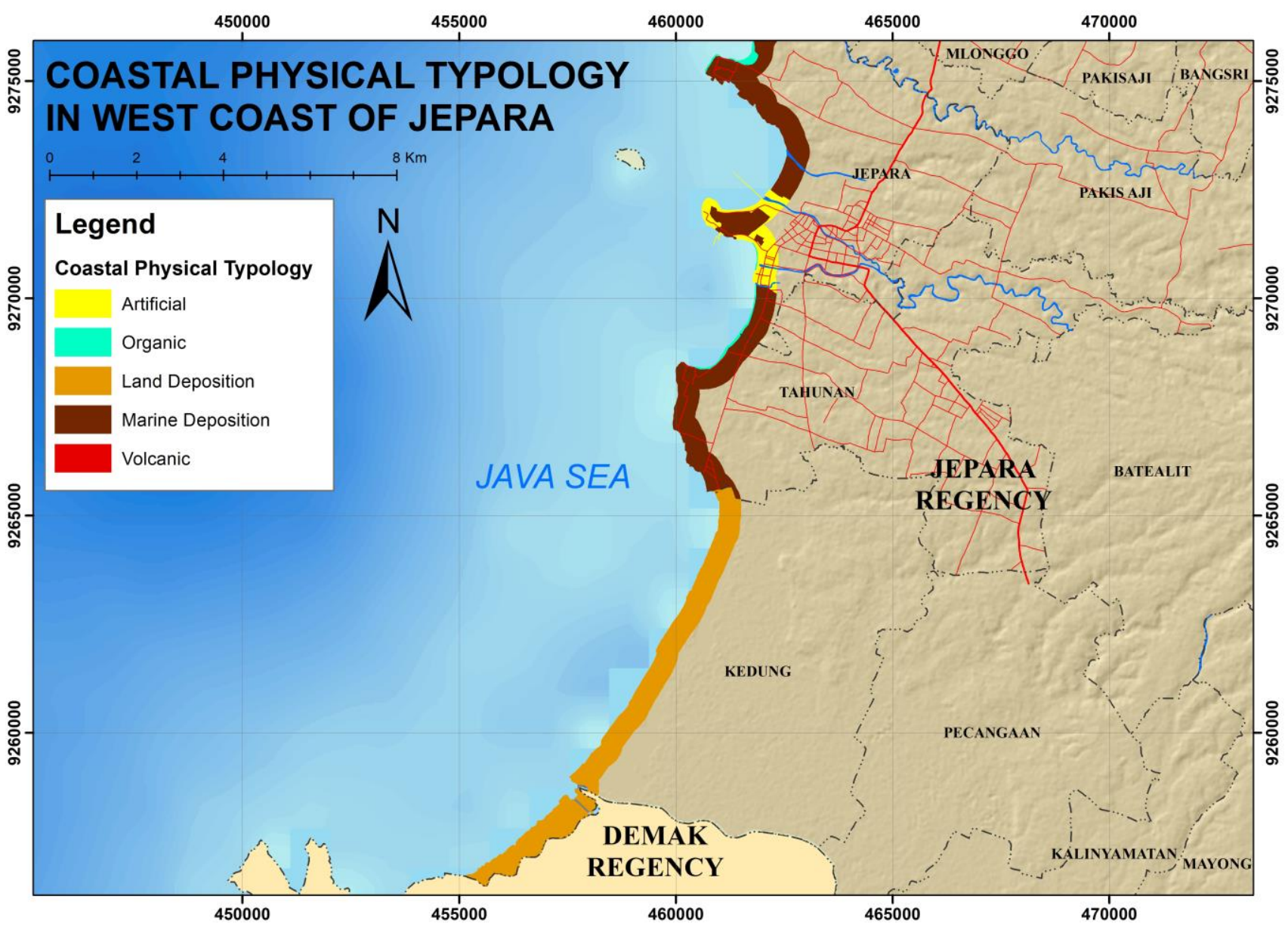

Figure 7. Coastal physical typology map of the west coast of Jepara Regency

The main material source in the land deposition coast in Kedung Subdistrict comes from sediments transported by Serang River and Wulan River in the southwest of Jepara Regency, which are subsequently deposited on the coast of Kedung District by coastal run-off. Marine deposition coast is the result of weathering processes of volcanic rocks as the beginning of the formation process of volcanic coastal areas in the Muria Peninsula, while artificial coastal physical typologies are formed due to human intervention.

The coastal physical typology class of the northwest part of Jepara Regency can be seen in Figure 8. At a scale of 1: 100,000, the coast in Mlonggo District consists of marine deposition coast. However, those directly adjacent to the shoreline are organic coast because there are many coral reefs along the coast of 
Mlonggo District. The dominant land cover in Mlonggo District is rice fields and ponds. The coast in the Bangsri District consists of marine deposition coast. However, those directly adjacent to the shoreline are organic coast because along the coast of Bangsri District there are also many coral reefs, such as in Mlonggo sub district. The dominant land cover in Bangsri Sub-district is rice fields. Coastal in Kembang sub district consist of artificial, organic and marine deposition coasts. Coastal physical typology class in Kembang sub district which is border with Bangsri District until Tanjung Jati PLTU, includes an artificial coastal physical typology class. Meanwhile, the beach to the east of Tanjung Jati electric steam power plant (PLTU), which borders the shoreline has marine deposition coast, with beach material in the form of iron sand, such as in Punuk Sapi Beach, which is widely used for rubber and teak plantations. The dominant land cover in Kembang District is rice fields, non-residential buildings, and plantations with hard woody plants.

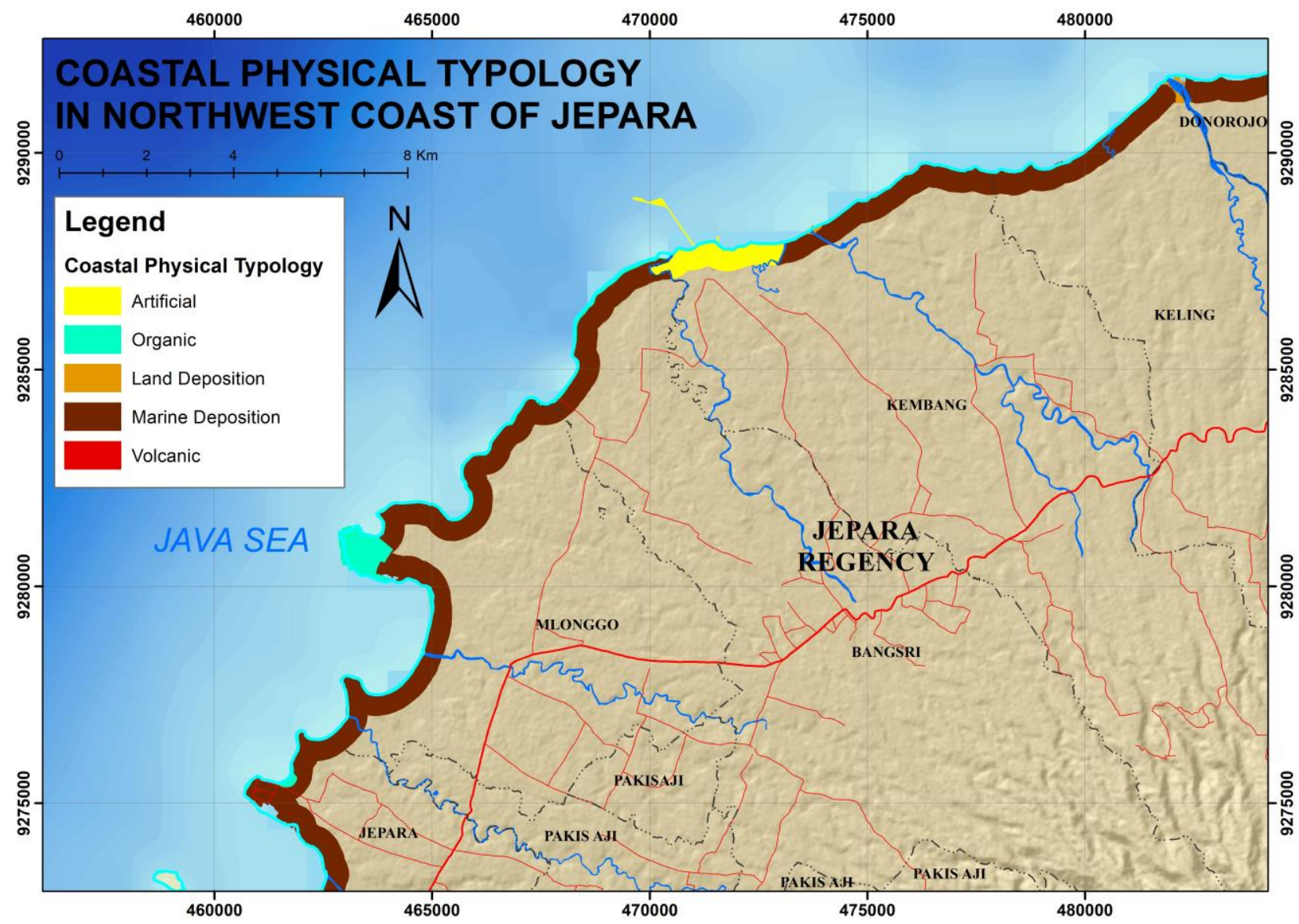

Figure 8. Coastal physical typology map of the northwest coast of Jepara Regency

The coastal physical typology class of the northern part of Jepara Regency can be seen in Figure 9. At a scale of 1: 100,000, the coast in Keling sub district consists of marine deposition coast, with the dominant land cover class being stretches of volcanic sand beach and plantations with hard woody plants. The coastal area in Donorojo sub district consist of marine deposition, land deposition, and volcanic coasts, with the dominant land cover class being volcanic sand beach, ponds and rice fields. Coastal physical typology classes of marine deposition are along the coast in Donorojo Sub-district so they have sandy beaches, but for Ujungwatu and Clering Villages they have muddy material which is used as pond land. Meanwhile, volcanic coast are in two locations, namely at the Portuguese Fort Beach and Guamanik Beach, which are characterized by steep hilly topography with rock material from the remaining volcanic activity of Genuk Mount. 


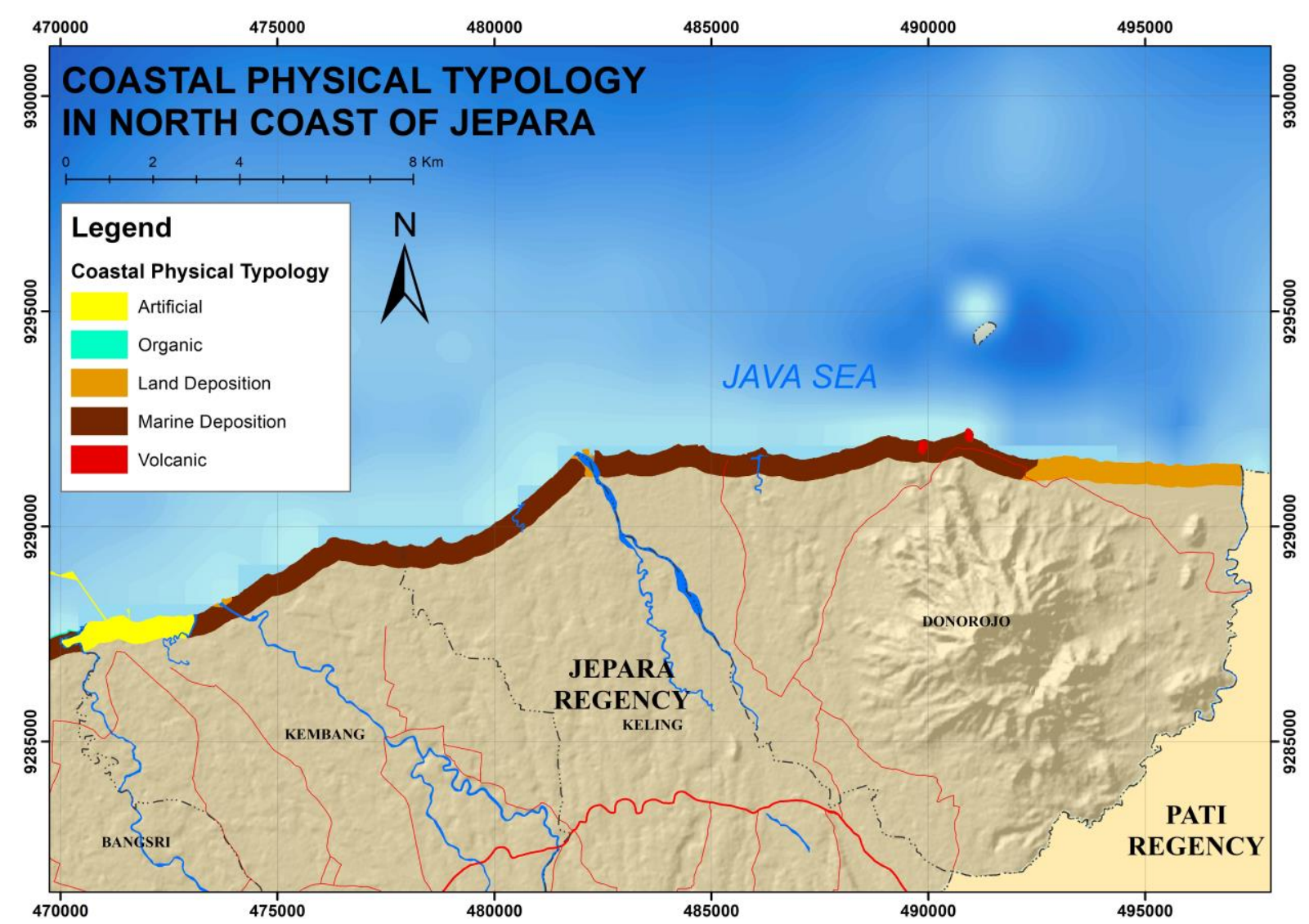

Figure 9. Coastal physical typology map of the northern coast of Jepara Regency

The difference in various shoreline derived from water index transformation are shown in Table 7. The shoreline resulting from MNDWI transformation with a threshold of 0 gives the lowest RMSE value among the eight shorelines resulting from the transformation of another index, while the shoreline resulting from NDWI transformation with a threshold of 0 gives the highest RMSE value. The eight index transformations can only produce the best shoreline map with class 3 horizontal accuracy according to the Technical Guidelines for Basic Map Accuracy (Rokni et al., 2014). However, this shows that several types of water index transformation applied in this study meet the standard geometry accuracy of RBI maps on 1: 100,000 scale in horizontal class 3 accuracy, even in addition to AWEInsh with 0.05 and NDWI thresholds with threshold 0 , water index transformation others are included in the horizontal accuracy of class 1 on the standard geometry accuracy of a 1: 250,000 scale RBI map.

Table 7. The difference in various shoreline derived from water index transformation

\begin{tabular}{|cccccc|c} 
No & Shoreline & Length $(\mathrm{m})$ & $\begin{array}{c}\text { Difference with } \\
\text { References }(\mathrm{m})\end{array}$ & $\begin{array}{c}\text { RMSE } \\
(\mathrm{m})\end{array}$ & $\begin{array}{c}\text { Horizontal } \\
\text { accuracy }(\mathrm{m})\end{array}$ & $\begin{array}{c}\text { Class in } \\
1: 100.000 \text { scale }\end{array}$ \\
\hline $\mathbf{1}$ & $\begin{array}{c}\text { PlanetScope } \\
\text { Reference }\end{array}$ & $95.224,41$ & - & - & - & - \\
\hline $\mathbf{2}$ & AWEInsh $\mathrm{t}=0$ & $83.494,58$ & $11.729,83$ & 30,08 & 45,64 & 3 \\
\hline $\mathbf{3}$ & AWEInsh $\mathrm{t}=0,05$ & $82.499,69$ & $12.724,72$ & 38,41 & 58,29 & - \\
\hline $\mathbf{4}$ & AWElsh $\mathrm{t}=0$ & $85.167,14$ & $10.057,27$ & 27,06 & 41,06 & 3 \\
\hline $\mathbf{5}$ & AWEIsh $\mathrm{t}=-0,05$ & $102.161,65$ & $6.937,23$ & 27,15 & 41,20 & 3 \\
\hline $\mathbf{6}$ & MNDWI t $=0$ & $88.773,50$ & $6.450,91$ & 25,33 & 38,44 & 3 \\
\hline $\mathbf{7}$ & MNDWI $\mathrm{t}=0,15$ & $79.492,49$ & $15.731,93$ & 28,88 & 43,83 & 3 \\
\hline $\mathbf{8}$ & NDWI $\mathrm{t}=0$ & $83.371,42$ & 11.853 & 43,77 & 66,43 & - \\
\hline $\mathbf{9}$ & NDWI $=-0,15$ & $97.648,92$ & $2.424,50$ & 32,89 & 49,92 & 3 \\
\hline
\end{tabular}


The shoreline that meets the horizontal accuracy of the RBI map shows that the water index transformation method on Landsat $8 \mathrm{OLI}$ imagery can be selected as an alternative in obtaining and updating semi-automatic shoreline data. It is said to be semi-automatic because the shoreline is not directly obtained from digital image processing, but it is through the selection stage, namely the outer boundary between water and non-water pixels is identified as a shoreline so that the object is classified as pixels of water but still on land will be eliminated because the boundary between water and non-water pixels in that location does not include the shoreline.

Because it is used for analysis, it must be ensured that tentative maps of coastal physical typologies and tentative maps of land cover that have been made are correct, as evidenced by accuracy tests. For accuracy testing, land cover and coastal physical typology maps are overlaid so that maps of land units are obtained, with 22 class of land unit classes and 136 population numbers. Using the Slovin formula, a minimum of 101 samples are needed, while samples are collected is 116 . Using the error matrix table, the accuracy of the tentative overall map of the coastal physical typology is $89.66 \%$ and the kappa index is 0.85 , while the overall accuracy of the tentative map of the land cover is $86.21 \%$ and the kappa index is 0,84 . If the minimum accuracy received is $85 \%$ then a tentative map of the coastal typology and land cover that has been made can be used for analysis.

After going through the field stage and testing accuracy, a tentative map of the coastal typology and land cover is reinterpreted so that the results of the analysis are not mistaken. Based on a physical typology map of coastal reinterpretation there are 5 physical coastal typology classes in the study area. Meanwhile, for the reinterpretation land cover map there are 11 land cover classes in the study area, but only 10 classes of land cover are directly adjacent to the shoreline. The results of accuracy assessment on land cover maps show that classification errors occur in vegetation objects, such as gardens and mixed plants, rice fields, and other cultivated plants. This error occurs in a variety of vegetation conditions due to cropping rotation patterns so that the same object class in the field looks visually different in the image. Meanwhile, coastal physical typology maps have many errors in the classification between classes of land deposition and marine deposition, as well as between land and organic depositional classes.

Figure 10 shows the field conditions of the coastal physical typology class and land cover that is misclassified. Interpretation of coastal physical typologies through imagery is made using a matrix of determining coastal physical typologies in Table 1 and associations between coastal physical typologies and land cover, but conditions on the field are partly different. Examples are ponds associated with land deposition, but this applies to traditional ponds, while for ponds with cement or plastic bases, these activities can be carried out in other coastal physical typologies, such as marine deposition and organic coasts. This can be seen in Figure 11. Another example is the presence of coral reefs associated with physical coastal typology, but in certain conditions this is not necessarily true because there are several process dynamics that occur so that the resulting coastal material is a mixture of coral and sand fragments. This shows that the process of marine deposition or land deposition can also occur in the same location.
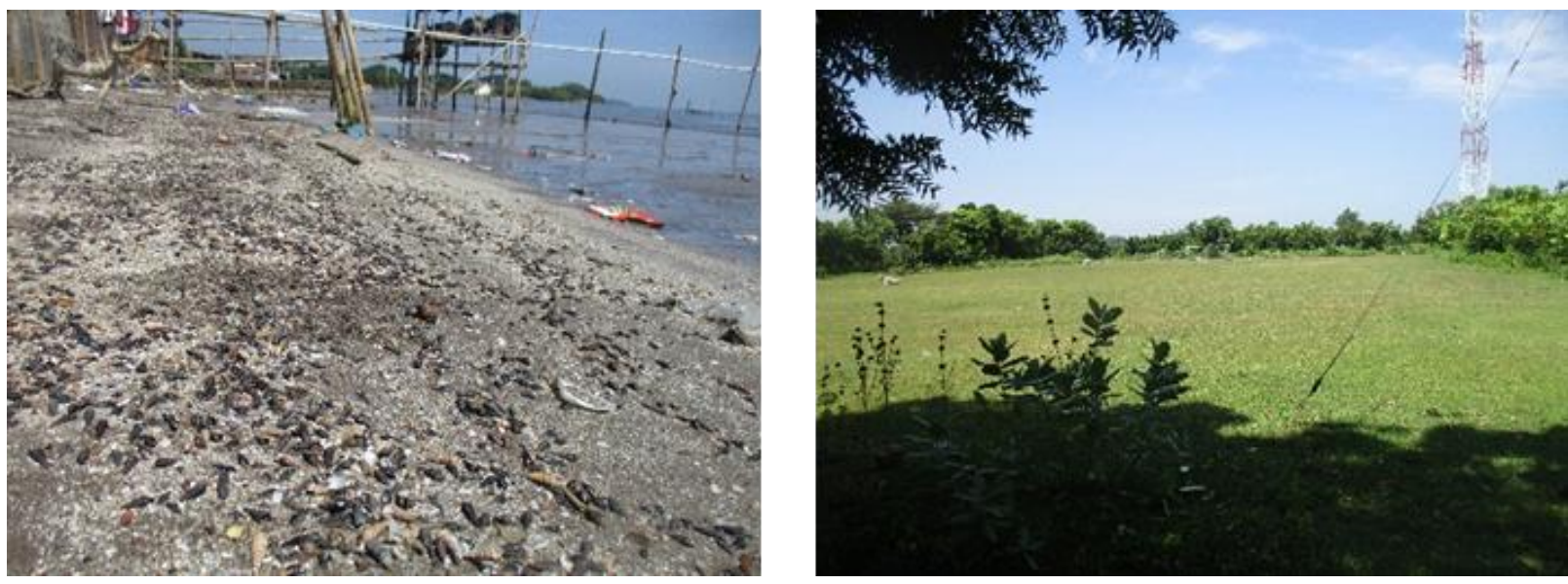

Figure 10. Organic classes are considered to be marine deposition (left) and other classes of cultivated plants that are considered rice fields (right) 

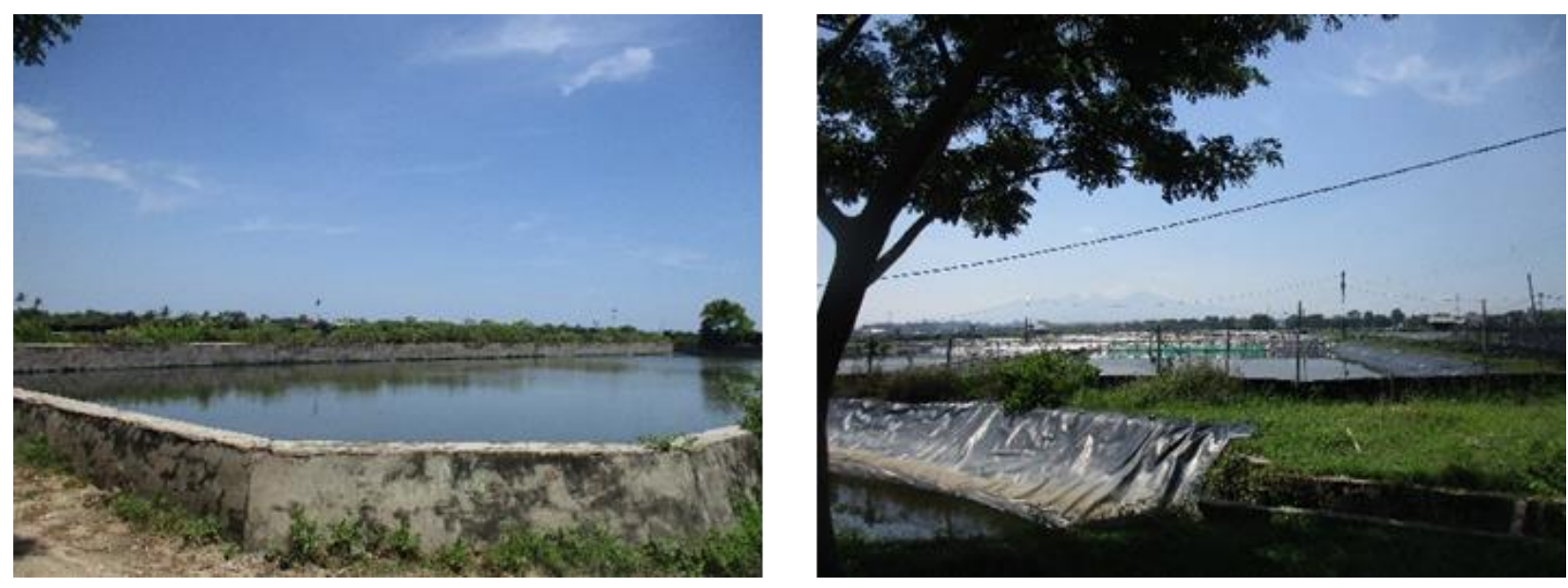

Figure 11. The condition of the pond in the physical typology of the organic coast (left) and marine deposition (right)

Table 8. Geometry accuracy of the shoreline in Jepara Regency in different coastal physical typologies resulting from NDWI, MNDWI, and AWEI on Landsat 8 OLI imagery

\begin{tabular}{cc|ccccccc}
\multirow{2}{*}{$\begin{array}{c}\text { Water } \\
\text { index }\end{array}$} & Threshold & \multicolumn{3}{|c}{ RMSE (in meter) per Coastal Physical Typology Class } & \multicolumn{2}{c}{ Descriptive Statistics } \\
\cline { 3 - 9 } & & Artificial & Organic & $\begin{array}{c}\text { Marine } \\
\text { deposition }\end{array}$ & $\begin{array}{c}\text { Land } \\
\text { deposition }\end{array}$ & Volcanic & Mean & StDev \\
\multirow{2}{*}{ NDWI } & 0 & 49,57 & 30,73 & 19,97 & 60,96 & 12,86 & 22,61 & 37,50 \\
& $-0,15$ & 24,13 & 21,16 & 20,23 & 46,62 & 13,58 & 19,67 & 26,37 \\
\hline MNDWI & 0 & 38,66 & 18,00 & 19,40 & 29,53 & 13,56 & 15,31 & 20,19 \\
& 0,15 & 54,26 & 14,16 & 15,84 & 35,24 & 10,00 & 15,61 & 24,31 \\
\hline AWElsh & 0 & 24,71 & 13,47 & 17,86 & 38,13 & 13,56 & 16,30 & 21,60 \\
& $-0,05$ & 25,64 & 22,99 & 16,54 & 35,94 & 13,60 & 17,39 & 20,86 \\
\hline AWEInsh & 0 & 54,79 & 14,96 & 17,54 & 36,83 & 10,12 & 16,10 & 25,42 \\
& 0,05 & 62,32 & 31,53 & 34,19 & 38,72 & 11,78 & 18,70 & 33,57 \\
\hline Descriptive & Mean & 20,55 & 11,92 & 12,23 & 25,40 & 9,43 & & \\
\hline Statistics & StDev & 39,16 & 18,40 & 16,99 & 32,50 & 8,20 & & \\
\hline & & & & & & & & \\
\hline
\end{tabular}

Based on Table 8, it can be seen the advantages and limitations of each water index transformation in shoreline extraction in the coastal physical typology. When viewed from the lowest RMSE value, NDWI excels in shoreline extraction compared to other index transformations in artificial coast. MNDWI excels in shoreline extraction compared to other index transformations in marine deposition, land deposition, and volcanic coasts. AWElsh excels in shoreline extraction compared to other index transformations in the organic coasts, while AWEInsh is not superior in any coastal physical typology. When viewed from the highest RMSE values, NDWI is not superior to other index transformations in shoreline extraction in land deposition coast. MNDWI is still superior compared to other index transformations in all coastal physical typologies. AWElsh is not superior to other index transformations in shoreline extraction in the volcanic coast. AWEInsh is not superior to other index transformations in shoreline extraction in the artificial, organic, and marine deposition coasts.

Explanations related to variations in shoreline geometry accuracy are as follows. Artificial coast consist of non-residential and residential buildings. The spectral reflection characteristics of the two objects are higher along with an increase in wavelength. Thus, MNDWI has higher geometry accuracy compared to NDWI, especially at the threshold setting 0 . However, the residential buildings around the coastal area of Jepara Sub-district is covered by clouds and cloud shadows so that the superiority of AWElsh can be seen 
from the results of geometry accuracy that shows the lowest value compared to MNDWI, NDWI, and AWEInsh at the threshold setting 0 . Even so, with the optimal threshold selection, NDWI with a threshold of -0.15 is able to provide the highest geometry accuracy compared to other water index transformations, even able to outperform AWElsh in minimizing influence cloud cover in the study area.

The organic coasts is dominated by non-volcanic sand beaches. The higher spectral reflectivity characteristics of soil objects along with the increase in wavelength, making the pixel value of the water object at AWEI will be more positive (and the pixels of land objects are more negative) compared to MNDWI and NDWI so that the shoreline has the highest geometry accuracy. The presence of cloud cover and cloud shadow makes the shoreline geometry accuracy of AWElsh the lowest value compared to other water index transformations.

The marine deposition coast is dominated by non-volcanic and volcanic sand beach. With the spectral reflection characteristics of soil objects as described previously, the shoreline of AWEI has the lowest geometry accuracy compared to MNDWI and NDWI. For land objects, AWEInsh will give more positive water object pixel values (and the pixels of land objects are more negative) compared to AWElsh because the constants used in AWEInsh for the middle and infrared bands are far greater than the constants used in AWElsh. This is also supported by relatively straight coastal geometry and more stable beach dynamics in the physical typology of coastal land deposition. Thus, the boundary between land-sea will look very contrasting. However, with an optimal threshold selection, MNDWI with a threshold of 0.15 can provide the lowest geometry accuracy compared to other water index transformations.

Land deposition coast is dominated by ponds. The spectral reflection characteristics of wet soil objects are high at the middle infrared wavelength, but low at far infrared wavelengths due to the influence of water uptake so that the pixel value of the water object in MNDWI will be more positive (and the pixels of land objects is more negative) compared to AWEI and NDWI so that the shoreline has the highest geometry accuracy, especially at the threshold setting 0 . In contrast, NDWI which uses only green bands and near infrared bands has the lowest geometry accuracy compared to other water index transformations. This is caused by errors in the classification of ponds filled with water as pixels of marine objects. In addition, other causes of the occurrence of errors in shoreline extraction in the land deposition coast are sediments near the coast, such as, tombolo, spit, and sand bar.

Volcanic coastal area is dominated by high land forest with not-too-tight canopy and rock material. Taking into account the spectral reflectivity characteristics of high vegetation objects in the near infrared band, high spectral reflection of soil objects in the far infrared band, and greater atmospheric scattering at blue wavelengths, the shorelines of NDWI and AWEInsh will be more positive (and pixels of land object is more negative) compared to MNDWI and AWElsh so the shoreline has the highest geometry accuracy, especially at the threshold setting 0 . AWEInsh uses near infrared and far infrared bands simultaneously so that the accuracy of AWEInsh geometry is higher than NDWI. However, with an optimal threshold selection, MNDWI with a threshold of 0.15 can provide the highest geometry accuracy compared to other water index transformations.

Examples of differences in shoreline position results for each water index transformation in the coastal physical typology class are presented in Figure 12. It can be seen that the shoreline extracted in marine deposition (Figure 12a) and volcanic coasts (Figure 12e) are relatively stable in each water index transformation. Errors in shoreline extraction due to cloud cover can be seen in the artificial (Figure 12b) and organic coasts (Figure 12c), and errors in shoreline extraction due to sediment can be seen in the land deposition coast (Figure 12d). 


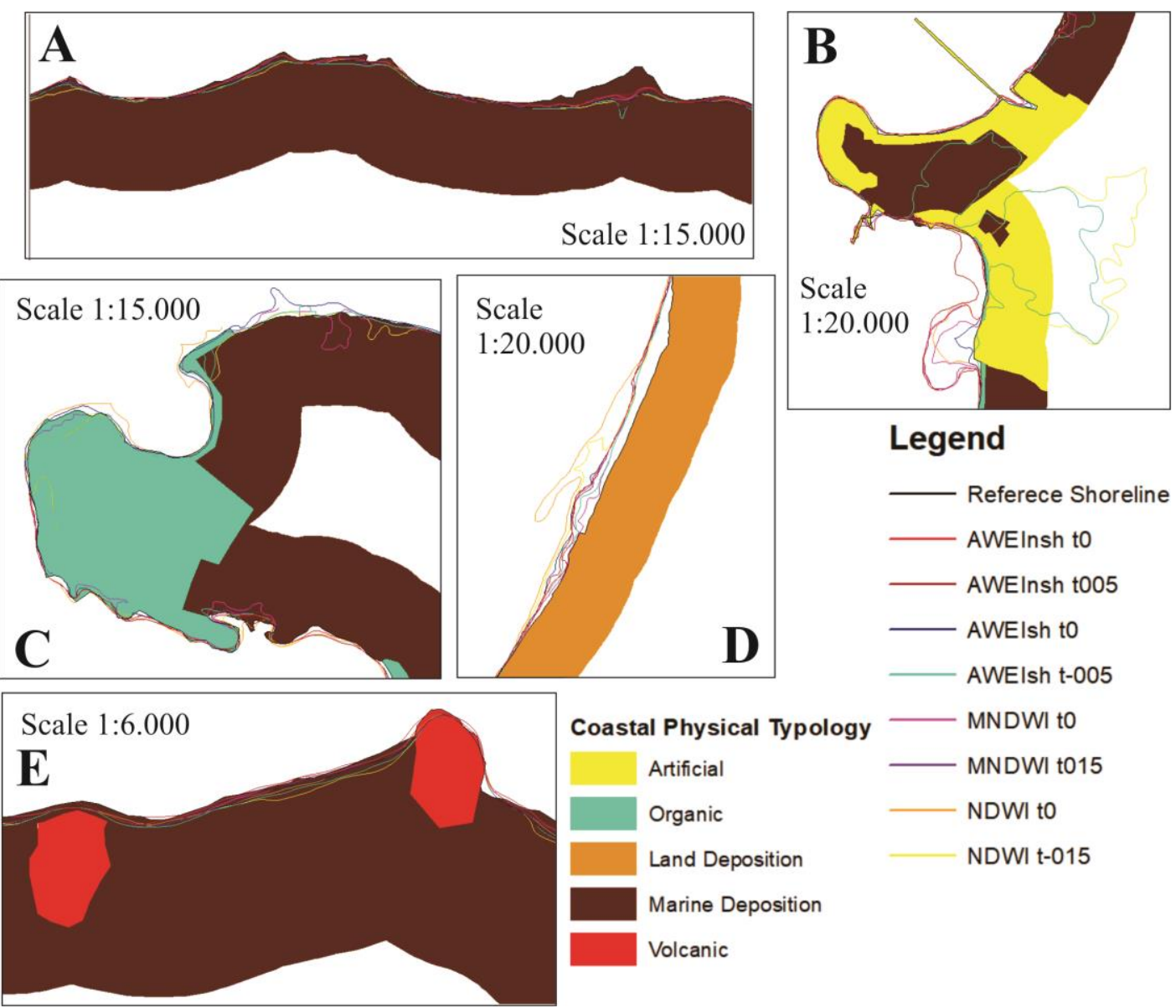

Figure 12. The difference in the position of the coastline results from each water index transformation in the coastal physical typology class

Table 9. Horizontal accuracy class of shoreline in Jepara Regency in different coastal physical typologies results from NDWI, MNDWI, and AWEI on Landsat 8 OLI imagery

\begin{tabular}{ccccccc} 
Water index & Threshold & \multicolumn{5}{c}{ Coastal Physical Typology Class } \\
\cline { 3 - 7 } & & Artificial & Organic & $\begin{array}{c}\text { Marine } \\
\text { deposition }\end{array}$ & $\begin{array}{c}\text { Land } \\
\text { deposition }\end{array}$ & Volcanic \\
\hline NDWI & 0 & 0 & 3 & 3 & 0 & 1 \\
& $-0,15$ & 3 & 3 & 3 & 0 & 2 \\
\hline MNDWI & 0 & 0 & 2 & 2 & 3 & 2 \\
\hline AWEIsh & 0,15 & 0 & 2 & 2 & 0 & 1 \\
\hline AWEInsh & 0 & 3 & 2 & 2 & 0 & 2 \\
& $-0,05$ & 3 & 3 & 2 & 0 & 2 \\
\hline & 0 & 0 & 2 & 2 & 0 & 1 \\
\hline
\end{tabular}

From Table 9, then it is known the feasibility of using each water index transformation from shoreline extraction in coastal physical typology. Judging from the coastal physical typology, all water index transformations used in this study are feasible to be applied to the volcanic, marine deposition, and organic coasts, with different horizontal accuracy classes for each water index transformation. Meanwhile, for artificial coast only AWEIsh and NDWI with a threshold of -0.15 are suitable for use, while for land 
deposition coast there is no single water index transformation that is suitable for use other than MNDWI with a threshold of 0 .

Similar to the water index transformation (Yang et al., 2015), the coastal physical typology is also ranked based on shoreline geometry accuracy statistics. The most consistent shoreline in the coastal physical typology when extracted with all water index transforms is volcanic (mean RMSE 9.43 $\pm 8.20 \mathrm{~m}$ ), marine deposition (mean RMSE $12.23 \pm 16,99 \mathrm{~m}$ ), organic (average RMSE $11.92 \pm 18.40 \mathrm{~m}$ ), land deposition (average RMSE $25.40 \pm 32.50 \mathrm{~m}$ ), and artificial (average RMSE $20.55 \pm 39,16 \mathrm{~m}$ ). Thus, whatever shoreline extraction method is used, the shoreline in the volcanic coast has the highest geometry accuracy compared to the shoreline in other coastal physical typologies.

\section{CONCLUSION}

Based on the results of the shoreline mapping using NDWI, MNDWI, and AWEI transformations, it is known that the shoreline length of each water index transformation shows results that vary between $80 \mathrm{~km}$ to $100 \mathrm{~km}$. The shoreline resulting from MNDWI transformation with threshold 0 gives the lowest RMSE value and highest horizontal accuracy among the eight shorelines resulting from the transformation of other indices, while the shoreline resulting from NDWI transformation with threshold 0 gives the highest RMSE value and lowest horizontal accuracy. AWEInsh with a threshold of 0.05 and NDWI with a threshold of 0 does not meet the horizontal accuracy of a 1: 100,000 RBI map, while other water index transforms are capable of producing shorelines that meet horizontal accuracy of class 3 on a 1: 100,000 RBI map according to the Technical Guidelines for Basic Map Accuracy.

Based on the calculation of shoreline geometry accuracy from the transformation of NDWI, MNDWI, and AWEI in the coastal physical typology, it is known that NDWI has the highest shoreline geometry accuracy compared to other index transformations on artificial coast (RMSE $=24.13 \mathrm{~m}$ ). MNDWI has the highest shoreline geometry accuracy on marine deposition coast (RMSE $=15.84 \mathrm{~m}$ ), land deposition coast (RMSE= $29.53 \mathrm{~m})$, and volcanic coast (RMSE= $10 \mathrm{~m})$. AWElsh has the highest shoreline geometry accuracy on organic coast (RMSE $=13.47 \mathrm{~m}$ ), while AWEInsh does not superior to any coastal physical typology.

\section{ACKNOWLEDGMENTS}

The author would like to thank the faculty for all the support. Thanks also to Dr. Nurul Khakhim, M.Sc. and Dr. Nur Mohammad Farda, M.Cs. from Geographic Information Science Department, Faculty of Geography, Universitas Gadjah Mada for suggestion and improvement in this study.

\section{REFERENCES}

Badan Informasi Geospasial. (2014). Peraturan Kepala Badan Informasi Geospasial Nomor 15 Tahun 2014 tentang Pedoman Teknis Ketelitian Peta Dasar.

Dulbahri. (1983). Laporan penelitian aplikasi citra Landsat skala 1: 250.000 untuk studi perubahan garis pantai di daerah Jawa Tengah dan Jawa Timur. book, Fakultas Geografi, Universitas Gadjah Mada, Departemen Pendidikan dan Kebudayaan.

Feyisa, G. L., Meilby, H., Fensholt, R., \& Proud, S. R. (2014). Automated Water Extraction Index: A new technique for surface water mapping using Landsat imagery. Remote Sensing of Environment, 140, 23-35. [Crossref]

Khakim, N. (2009). Kajian tipologi fisik pesisir Daerah Istimewa Yogyakarta untuk mendukung pengembangan dan pengelolaan wilayah pesisir. Sekolah Pasca Sarjana Institut Pertanian Bogor. Bogor.

Li, W., \& Gong, P. (2016). Continuous monitoring of coastline dynamics in western Florida with a 30-year time series of Landsat imagery. Remote Sensing of Environment, 179, 196-209. [Crossref]

McFeeters, S. K. (1996). The use of the Normalized Difference Water Index (NDWI) in the delineation of open water features. International Journal of Remote Sensing, 17(7), 1425-1432. [Crossref]

Pemerintah Kabupaten Jepara. (2012). Rencana Pembangunan Jangka Menengah Daerah Kabupaten Jepara Tahun 2012 - 2017. Jepara.

Rahardjo, N. (2003). Sebaran tipe pantai dan karakteristik lingkungan di pantai selatan jawa barat. Majalah Geografi Indonesia, 17(2003). 
Rokni, K., Ahmad, A., Selamat, A., \& Hazini, S. (2014). Water Feature Extraction and Change Detection Using Multitemporal Landsat Imagery. Remote Sensing, 6(5), 4173-4189. [Crossref]

Sinaga, T. P. T., \& Susiati, H. (2007). Studi Pemodelan Perubahan Garis Pantai di Sekitar Perairan Tapak PLTN Semenanjung Muria. Jurnal Pengembangan Energi Nuklir, 9(2).

Sun, F., Sun, W., Chen, J., \& Gong, P. (2012). Comparison and improvement of methods for identifying waterbodies in remotely sensed imagery. International Journal of Remote Sensing, 33(21), 6854-6875. [Crossref]

Sutanto, P. (2004). Perubahan fenomena geomorfik daerah kepesisiran di sekeliling Gunungapi Muria Jawa Tengah:: Kajian Paleogeomorfologi (phdthesis). [Yogyakarta]: Universitas Gadjah Mada.

Triatmojo, B. (2008). Teknik Pantai, Cetakan kelima. misc, Beta Offset, Provinsi Daerah Istimewa Yogyakarta.

Tucker, C. J., Grant, D. M., \& Dykstra, J. D. (2004). NASA's Global Orthorectified Landsat Data Set. Photogrammetric Engineering \& Remote Sensing, 70(3), 313-322. [Crossref]

$\mathrm{Xu}, \mathrm{H}$. (2006). Modification of normalised difference water index (NDWI) to enhance open water features in remotely sensed imagery. International Journal of Remote Sensing, 27(14), 3025-3033. [Crossref]

Yang, Y., Liu, Y., Zhou, M., Zhang, S., Zhan, W., Sun, C., \& Duan, Y. (2015). Landsat 8 OLI image based terrestrial water extraction from heterogeneous backgrounds using a reflectance homogenization approach. Remote Sensing of Environment, 171, 14-32. [Crossref] 